\title{
ANTISIPASI ATAS KERENTANAN PADA LEMBAGA PEMBIAYAAN SYARIAH MELALUI PENATAAN KEMBALI PERAN BI SEBAGAI PENGAWAS JASA KEUANGAN BERBASIS EKONOMI ISLAM SESUAI UU NO. 21 TAHUN 2011
}

\author{
Yudi Akhmad Sadeli \\ Akuntansi, STIEM Bongaya, \\ Email : yudi.tinulu@gmail.com
}

(Diterima: 26-Juli-2018; di revisi: 12-Agustus-2018; dipublikasikan: Oktober-2018)

\begin{abstract}
Abstrak:
Penelitian ini bertujuan untuk menganalisis peran dari BI dalam menjalankan tugas pengaturan dan pengawasan terhadap Lembaga Keuangan di Indonesia sesuai dengan UU No.21 Tahun 2011 sebagai wujud antisipasi kerentanan sistem keuangan di Indonesia dan untuk menganalisis implementasi dari pelaksanaan fungsi pengaturan dan pengawasan yang akan dilaksanakan BI sesuai dengan UU No.21 Tahun 2011 sebagai wujud antisipasi kerentanan sistem keuangan di Indonesia.

Hasil penelitian menunjukkan bahwa Bank Indonesia berkedudukan sesuai dengan UU No. 21 Tahun 2011 Pasal 40 ayat 1 dan 2. BI sendiri memiliki independensi yang dapat diharapkan mengatur dan mengawasi LK tanpa intervensi dan mampu lebih tegas guna stabilitas jalannya lembaga keuangan, sesuai dengan UU No. 21 Tahun 2011 pasal 2.Implementasi dari fungsi pengaturan dan pengawasan yang dilaksanakan BI sesuai dengan UU No. 21 Tahun 2011 bersifat independen. Pada UndangUndang No 21 Tahun 2011 tentang BI pasal 66 ayat 2 sendiri disebutkan bahwa Bank Indonesia, menteri Keuangan, dan Bapepam-LK menyampaikan laporan atas pelaksaan fungsi, tugas dan wewenang sebagaimana dimaksud pada ayat (1) kepada BI. BI sendiri memiliki implementasi dalam mengatur dan mengawasi sektor perbankan yang merupakan pengalihan dari tugas Bank Indonesia, sektor pasar modal, perasuransian, dana pensiun dan lembaga pembiayaan syariah yang merupakan pengalihan dari Bapepam-LK.
\end{abstract}

Keywords: Bank Indonesia; Lembaga pembiayaan syariah; Lembaga Keuangan; Stabilisasi Ekonomi Islam; UU No.21 Tahun 2011; Pengawasan

\section{PENDAHULUAN}

Perekenomian Indonesia dipandang banyak kalangan telah membuahkan sejumlah prestasi (Syukron, 2013). Namun juga, di sisi lain perekonomian Indonesia masih memiliki sejumlah tantangan yang harus dihadapi. Salah satu tantangan yang dimaksud berada pada sektor keuangan dalam menggerakkan perekonomian berupa dana atau permodalan. Hingga saat ini, dirasakan akses kepada lembaga-lembaga keuangan khususnya kelompok menengah ke bawah masih cukup terbatas (Nasihin, 2012).

Kerentanan atas, lembaga keuangan dalam dinamika masyarakat yang cepat berkembang seperti saat ini, memainkan peran yang krusial dalam kehidupan sehari-hari (Syukron, 2013).

Lembaga keuangan membutuhkan suatu terobosan untuk pemberdayaan dan penataan sistem keuangan, sehingga dapat menjaga 
stabilitas perekonomian. Tujuan utama dari terbentuknya sistem keuangan adalah untuk menghimpun dana dari masyarakat dan mendistribusikannya kepada peminjam, lalu dipergunakan untuk membiayai produksi dan/atau untuk mendorong sistem perdagangan, sehingga ekonomi masyarakat tersebut dapat berkembang dan meningkat.

Untuk mencapai suatu sistem perbankan, otoritas-otoritas yang berkegiatan di dalam kedua sistem tersebut harus juga kuat, dan antisipatif terhadap goncangan-goncangan yang terjadi. Goncangan-goncangan tersebut erat kaitannya dengan era globalisasi yang semakin berkembang di mana lembaga keuangan dan perbankan relatif terbuka.

Di Indonesia sendiri kejutan tersebut terjadi pada akhir tahun 90-an, di mana Indonesia mengalami krisis ekonomi dan moneter yang membuat rupiah terdepresiasi terhadap US\$ secara tajam. Pada saat itu terbesit dalam pemikiran BJ.Habibie untuk memperkuat status independensi dari Bank Indonesia sebagai suatu lembaga (Ali, 2003). Hal tersebut didasari pemikiran bahwa Bank Indonesia sebagai bankers of bank telah melakukan berbagai upaya positif untuk mengembalikan peran bank-bank umum kepada fungsinya sebagai intermediary institution dan mendorong terjadinya penggabungan (merger) tehadap bank-bank swasta untuk kepentingan efektifitas managerial dan permodalan (Ali, 2003).

Ide pemisahan fungsi pengawasan dari bank sentral ini datang dari Helmut Schlesinger, mantan Gubernur Bundesbank (bank sentral Jerman) yang pada waktu penyusunan RUU bank Indonesia (kemudian menjadi Undang-Undang
No. 23 Tahun 1999) bertindak sebagai konsultan, yang mengadopsi pola bank sentral Jerman yang tidak mengawasi bank (Sitompul, 2005). Gagasan tersebut lalu dikenal dengan gagasan pembentukan BI yang memiliki tugas untuk melakukan pengawasan sektor jasa keuangan berbasis ekonomi islam.

Konsep dari BI sendiri adalah merupakan suatu transformasi dari lembaga pengawasan sektor keuangan, di mana merupakan sebuah lembaga pengawasan jasa keuangan berbasis ekonomi islam yang meliputi industri perbankan, pasar modal, reksadana, perusahaan pembiayaan, dana pensiun dan asuransi (Syukron, 2012). BI ini memiliki tugas untuk melakukan pengawasan terhadap bank dan perusahaan sektor jasa keuangan berbasis ekonomi islam lainnya termasuk di dalamnya perusahaan asuransi, dana pensiun, modal ventura, perusahaan pembiayaan, serta badan-badan lain yang menyelenggarakan pengelolaan dana masyarakat.

Proses globalisasi dalam sistem keuangan dan pesatnya kemajuan di bidang teknologi informasi serta inovasi finansial telah menciptakan sistem keuangan yang sangat kompleks, dinamis, dan saling terkait antar-sub sektor keuangan baik dalam hal produk maupun kelembagaan. Adanya lembaga jasa keuangan berbasis ekonomi islam yang memiliki hubungan kepemilikan di berbagai sub sektor keuangan (konglomerasi) telah menambah kompleksitas transaksi dan interaksi antar lembaga jasa keuangan berbasis ekonomi islam di dalam sistem keuangan.

Banyaknya permasalahan lintas sektoral di sektor jasa keuangan berbasis ekonomi islam, yang meliputi tindakan moral hazard, belum 
Yudi Akhmad Sadeli, Antisipasi Atas Kerentanan Pada Lembaga Pembiayaan Syariah Melalui Penataan Kembali Peran BI Sebagai Pengawas Jasa Keuangan Berbasis Ekonomi Islam Sesuai UU no. 21 tahun 2011 |39

optimalnya perlindungan konsumen jasa keuangan berbasis ekonomi islam, dan terganggunya stabilitas sistem keuangan (Syukron, 2013).

\section{Dalam UU No.21 Mengenai BI} disebutkan tentang perlunya dicapai mekanisme koordinasi yang lebih efektif di dalam menangani permasalahan yang timbul dalam sistem keuangan sehingga dapat lebih menjamin tercapainya stabilitas sistem keuangan. Hal itu juga dimaksudkan agar pengaturan dan pengawasan terhadap keseluruhan kegiatan jasa keuangan berbasis ekonomi islam dengan dilakukan secara terintegrasi.

Dalam UU No. 21 tahun 2011 juga terdapat fungsi BI, yaitu mengawasi aturan main yang sudah dijalankan dari forum stabilitas keuangan, menjaga stabilitas sistem keuangan, melakukan pengawasan non-bank dalam struktur yang sama seperti sekarang, pengawasan bank keluar dari otoritas Bank Indonesia sebagai bank sentral dan dipegang oleh lembaga baru (Nasihin, 2012).

Seiring dengan perkembangan lembaga tersebut nantinya tujuan dalam pembentukan BI sendiri adalah untuk wewenang Bank Indonesia dalam melaksanakan kebijakan moneter secara berkelanjutan, konsisten, dan transparan dengan mempertimbangkan kebijakan umum pemerintah di bidang perekonomian; untuk mengatasi kompleksitas keuangan global dari ancaman krisis; untuk menciptakan satu otoritas yang lebih kuat dengan memiliki sumber daya manusia dan tenaga ahli yang mencukupi.

Menurut Deputi Gubernur Bank Indonesia Muliaman D. Hadad sendiri terdapat 4 (empat) pilar sektor keuangan global yang menjadi agenda BI (Setyawan, 2012). Pertama, kerangka kebijakan yang kuat untuk menanggulangi krisis. Kedua, persiapan resolusi terhadap lembagalembaga keuangan yang ditenggarai bisa berdampak sistemik. Ketiga, lembaga keuangan membuat surat wasiat jika terjadi kebangkrutan sewaktu-waktu dan keempat transparansi yang harus dijaga (Andriansyah, 2009).

Dalam kegiatannya, BI akan memiliki kaitan yang sangat erat dengan Bank Indonesia dalam merumuskan ketentuan yang berkaitan dengan pengawasan, serta membutuhkan keterangan dan uraian dari Bank Indonesia mengenai data-data makro yang diperlukan. Keberadaan BI sebagai suatu lembaga pengawasan sektor jasa keuangan berbasis ekonomi islam di Indonesia perlu mendapat perhatian, oleh karena itu harus dipersiapkan dengan baik segala hal untuk mendukung keberadaan BI tersebut. Undang-Undang tentang BI pada dasarnya memuat ketentuan tentang organisasi dan tata kelola (governance) dari lembaga yang memiliki otoritas pengaturan dan pengawasan terhadap sektor jasa keuangan berbasis ekonomi islam (Daniar, 2014).

Sedangkan ketentuan mengenai jenis-jenis produk jasa keuangan berbasis ekonomi islam, cakupan dan batas-batas kegiatan lembaga jasa keuangan berbasis ekonomi islam, kualifikasi dan kriteria lembaga jasa keuangan berbasis ekonomi islam, tingkat kesehatan dan pengaturan prudensial serta ketentuan tentang jasa penunjang sektor jasa keuangan berbasis ekonomi islam dan lain sebagainya yang menyangkut transaksi jasa keuangan berbasis ekonomi islam diatur dalam undang-undang sektoral tersendiri, yaitu Undang-Undang tentang 
perbankan, pasar modal, usaha perasuransian, dana pensiun, dan peraturan perundangundangan lain yang terkait dengan sektor jasa keuangan berbasis ekonomi islam lainnya (Dewianty, 2012).

Oleh karena itu, berdasarkan uraian-uraian di atas, dipandang perlu untuk sebuah analisis mengenai dapat lebih dalam menelaah BI sebagai bagaian dari kebijakan publik, sebagai antisipasi kerentanan sistem keuangan di Indonesia melalui pengawasan terhadap lembaga keuangan lainnya berdasarkan UU No 21. Tahun 2011.

Berdasarkan pemaparan di atas, maka dilakukan penelitian dengan tujuan untuk menganalisis peran dari BI dalam menjalankan tugas pengaturan dan pengawasan terhadap Lembaga Keuangan di Indonesia sesuai dengan UU No.21 Tahun 2011 sebagai wujud antisipasi kerentanan sistem keuangan di Indonesia serta Untuk menganalisis implementasi dari pelaksanaan fungsi pengaturan dan pengawasan yang akan dilaksanakan BI sesuai dengan UU No.21 Tahun 2011 sebagai wujud antisipasi kerentanan sistem keuangan di Indonesia.

\section{METODE}

\section{Metode Penelitian}

Metode yang digunakan adalah Metode penelitian deskriptif, metode deskriptif adalah metode yang digunakan untuk menggambarkan atau menganalisa suatu hasil penelitian tetapi tidak digunakan untuk membuat kesimpulan yang lebih luas (Sugiyono, 2011:29)..

\section{Objek Penelitian}

Objek penelitian ini adalah peran dari BI dalam menjalankan tugas pengaturan dan pengawasan terhadap Lembaga Keuangan di
Indonesia sesuai dengan UU No.21 Tahun 2011 sebagai wujud antisipasi kerentanan sistem keuangan di Indonesia.

\section{HASIL DAN PEMBAHASAN}

\section{Peran BI di Indonesia}

BI sebagai lembaga independen. Maksudnya adalah lembaga yang bertugas mengatur dan mengawasi lembaga keuangan bebas dari campur tangan pihak manapun kecuali untuk hal-hal yang disebutkan secara tegas dalam UU. Lebih jauh dalam penjelasan umum UU disebutkan bahwa BI dalam menjalankan tugas dan kedudukannya berada di luar pemerintah. Jadi, seharusnya tidak terpengaruh oleh pemerintah (independen). Meski secara normatif disebutkan bahwa BI adalah lembaga independen, pada beberapa kalangan masih timbul keraguan akan independensi BI tersebut (Daniar, 2014).

Lebih lanjut mengutip dari pernyataan Jonker Sihombing, mengenai penyatuan fungsi pengaturan dan pengawasan, disebutkan bahwa penyatuan fungsi pengaturan dan pengawasan kegiatan jasa keuangan berbasis ekonomi islam di sektor perbankan, pasar modal, perasuransian, dana pensiun, lembaga pembiayaan syariah, serta lembaga jasa keuangan berbasis ekonomi islam lainnya pada satu tangan dapat memiliki nilai efisiensi, mengingat pengawasan atas berbagai kegiatan di maksud selama dekade terakhir berada di tangan terpisah (Sihombing, 2012).

Dalam melakukan pengawasan BI berwenang melakukan pemeriksaan, penyidikan, perlindungan konsumen hingga pemberian sanksi bagi suatu jasa keuangan berbasis ekonomi islam. Perlindungan yang diberikan oleh BI mencakup pencegahan kerugian konsumen, pelayanan 
Yudi Akhmad Sadeli, Antisipasi Atas Kerentanan Pada Lembaga Pembiayaan Syariah Melalui Penataan Kembali Peran BI Sebagai Pengawas Jasa Keuangan Berbasis Ekonomi Islam Sesuai UU no. 21 tahun 2011 |41

pengaduan konsumen yang dirugikan, dan pembelaan hukum (Nasihin, 2012). Dalam melakukan pembelaan hukum, BI berwenang mengajukan gugatan untuk memperoleh kembali harta kekayaan milik konsumen yang dirugikan atau mengajukan gugatan ganti kerugian sebagai pelanggaran akibat pelanggaran atas perundang undangan di sektor jasa keuangan berbasis ekonomi islam. Dengan demikian dalam upaya memberikan perlindungan yang lebih baik bagi konsumen (dalam hal terjadi pengaduan), BI berwenang melakukan tindakan-tindakan mulai dari menerima pengaduan, memfasilitasi penyelesaian pengaduan, memeriksa dan menyelidik BI, pelaku dan/atau penunjang jasa keuangan berbasis ekonomi islam, mengajukan gugatan pengembalian harta kekayaan pihak yang dirugikan, mengajukan gugatan ganti rugi hingga menetapkan sanksi administratif dan memerintahkan atau melakukan tindakan tertentu kepada BI untuk menyelesaikan pengaduan konsumen yang dirugikan BI yang dimaksud (Kusumaningtuti, 2009).

Peran BI dalam Menjalankan Tugas Pengaturan dan Pengawasan Menurut UU No. 21 Tahun 2011 Sebagai Antisipasi Kerentanan Sistem Ekonomi Islam

Jika dikaji lebih mendalam fungsi tugas dan wewenang BI dengan Bank Indonesia telah berbeda dan memiliki suatu susunan yang berbeda organisasi dan telah diatur oleh Undang-Undang, di mana sesuai dengan isi UU Nomor 21 Tahun 2011 tentang BI pasal 40 ayat 1, yang berbunyi:

"Dalam hal Bank Indonesia untuk
melaksanakan fungsi, tugas dan
wewenangnya memerlukan pemeriksaan
khusus terhadap bank tertentu, Bank
Indonesia dapat melakukan pemeriksaan

langsung terhadap bank tersebut dengan menyampaikan pemberitahuan secara tertulis terlebih dahulu kepada BI" (Kusumaningtuti, 2009)

Pada dasarnya wewenang pemeriksaan terhadap bank adalah wewenang BI. Namun, dalam hal Bank Indonesia melaksanakan fungsi, tugas, dan wewenangnya membutuhkan informasi melalui kegiatan pemeriksaan bank, Bank Indonesia dapat melakukan pemeriksaan secara langsung terhadap bank tertentu yang masuk systemically important bank dan/atau bank lainnya sesuai dengan kewenangan Bank Indonesia di bidang macroprudential (Dewianty, 2012). Ini adalah pembatasan kewenangan pengaturan dan pengawasan antara BI dan Bank Indonesia, di mana pada sisi microprudential BI berwenang dan pada macroprudential Bank Indonesia yang memiliki wewenang.

Untuk kelancaran kegiatan pemeriksaan oleh Bank Indonesia, pemberitahuan secara tertulis dimaksud paling sedikit memuat tujuan, ruang lingkup, jangka waktu, dan mekanisme pemeriksaan. Untuk pemeriksaan secara langsung, sejatinya nanti Bank Indonesia akan merekomendasikan BI untuk melakukannya secara berkala maupun pada saat-saat yang dianggap perlu (Setyawan, 2012). Selanjutnya, BI akan juga dapat melakukan pemeriksaan terhadap perusahaan induk, perusahaan anak, pihak-pihak terkait, pihak terafiliasi dan juga debitur bank. Pihak-pihak tersebut wajib memberikan kepada tim pemeriksa Bank Indonesia yang berkenaan dengan a) Keterangan dan data yang diminta; b) Kesempatan untuk melihat semua pembukuan, dokumen, dan sarana fisik yang berkaitan dengan kegiatan usahanya, 
c) Hal-hal lain yang diperlukan (Sihombing, 2011).

Dengan adanya kewenangan yang dimiliki BI untuk membuat/ menetapkan peraturan pelaksanaan dari tugas pengaturan dan pengawasan kegiatan jasa keuangan berbasis ekonomi islam dimaksudkan agar BI dapat bertindak independen secara nyata. Kewenangan tersebut identik dengan yang sebelumnya dimiliki Bank Indonesia serta kewenangan yang dimiliki Bapepam-LK sebagai self regulatory organization (Nasihin, 2012). Ketentuan ini secara implisit dimaksudkan untuk mendukung keberadaan BI sebagai lembaga baru yang sanggup melaksanakan fungsi dan tugasnya dengan tetap mempertahankan independensinya.

Dalam kenyataanya peran BI untuk membantu ekonomi islam sekalipun harus tetap berkoordinasi dengan BLPS, dan Kementrian Keuangan, baik melalui forum Koordinasi Stabilitas Sistem Keuangan (KSSK) maupun di luar forum tersebut. Keberadaan Forum ini meskipun dimaksudkan hanya sebatas koordinasi namun dalam pelaksaannya dpat saja mereduksi independensi yang disandang BI, terutama apabila dilihat beberapa Pasal pada UU tersebut, yakni: a) ketentuan pada Pasal 45 ayat (1) c yang menyatakan bahwa KSSK membuat rekomendasi kepada setiap anggota untuk melaksanakan tindakan dan/ atau membuat kebijakan dalam rangka memelihara stabilitas sistem keuangan, dan b) ketentuan pada Pasal 44 ayat (3) yang menyatakan bahwa pengambilan keputusan dalam rapat KSSK dilakukan berdasarkan musyawarah untuk mufakat (Sihombing, 2011). Pengambilan keputusan berdasarkan suara terbanyak hanya dilakukan dalam hal musyawarah untuk mufakat tidak tercapai. Bagaimanaun juga, pelaksanaan musyawarah untuk mufakat dalam kadar tertentu dapat mengurangi independensi masing-masing lembaga yang harus bermusyawah tersebut.

Mengingat ketentuan pada UU yang menyebutkan bahwa lembaga BI hanya 1 (satu) dari 4 (empat) anggota KSSK, maka suara BI dalam setiap konsultasi maupun koordinasi pada tingkat KSSK menjadi hanya sebagian kecil dibandingkan dengan pendapat dan suara anggota lainnya dalam forum tersebut (Pradityo, 2011). Suka atau tidak suka, ketentuan ini dapat mereduksi independensi BI terutama apabila selalu diusahakan tercapainya musyawarah untuk mufakat pada keputusan-keputusan yang strategis.

\section{Implementasi dari Fungsi Pengaturan dan} Pengawasan oleh BI Sesuai Dengan UU No. 21 Tahun 2011 Sebagai Antisipasi Kerentanan Sistem ekonomi Islam

Pengawasan yang dilakukan Bank
Indonesia terhadap masing-masing bank pelaksana didasarkan pada ketentuan perundangundangan yang berlaku, dan kehadiran Bank Indonesia dalam fungsi pengaturan dan pengawasan ini tiak dapat diartikan sebagai upaya untuk meniadakan independensi perbankan yang diperiksa. Bank Indonesia merupakan lembaga yang independen menurut peraturan perundang-undangan yang berlaku, walau di masa lampau Pemerintah sering lupa memahami makna independensi Bank Indonesia tersebut (Kusumaningtuti, 2009).

Secara signifikan peran dari BI dan BI sendiri menurut Undang-Undang Nomor 21 
Yudi Akhmad Sadeli, Antisipasi Atas Kerentanan Pada Lembaga Pembiayaan Syariah Melalui Penataan Kembali Peran BI Sebagai Pengawas Jasa Keuangan Berbasis Ekonomi Islam Sesuai UU no. 21 tahun 2011 |43

Tahun 2011 telah terpisah. Dalam pasal 69 ayat 1 huruf a menekankan bahwa tugas Bank Indonesia dalam mengatur dan mengawasi bank sebagaimana dimaksud Pasal 8 huruf c yang dialihkan ke BI adalah tugas pengaturan dan pengwasan yang berkaitan dengan microprudential sebagaiman dimaksud undangundang ini. Sebaliknya, Bank Indonesia tetap memiliki tugas pengaturan perbankan terkait macroprudential.

Berkaitan dengan kewenangan untuk mengatur perbankan di atas, didalamnya melekat pula tindakan-tindakan yang berkaitan dengan merger, konsolidasi, akuisisi, sistem informasi bank dan sistem pelaporan atas aktivitas bank yang telah diterbitkan izin usahanya (Daniar, 2014). Dengan demikian meskipun pengawasan perbankan berada di tangan BI, Bank Indonesia masih mempunyai kewenangan monitor aktivitas bank dalam kaitan perizinan yang telah diberikan.

Pada Undang-Undang No 21 Tahun 2011 tentang BI pasal 66 ayat 2 sendiri disebutkan bahwa Bank Indonesia, menteri Keuangan, dan Badan Pengawas Pasar Modal dan Lembaga Keuangan menyampaikan laporan atas pelaksaan fungsi, tugas dan wewenang sebagaimana dimaksud pada ayat (1) kepada BI. Hal tersebut mengandung makna, bahwa ketentuan ini dimaksudkan agar Dewan Komisioner dapat menjalankan fungsi, tugas, dan wewenangnya secara efektif pada saat fungsi, tugas, dan wewenang tersebut beralih ke BI dari Bank Indonesia, Menteri Keuangan, dan Badan Pengawas Pasar Modal dan Lembaga Keuangan.

Oleh karena itu, Bank Indonesia akan tetap mengawasi kegiatan transfer dana dan kegiatan lainnya yang berkaitan dengan sistem pembayaran tersebut. Jika dilihat dengan seksama sebenarnya tidak ada yang salah dengan kebijakan di atas sepanjang koordinasi di antara kedua lembaga dimaksud. Dengan demikian akan jelas mana yang akan diatur dan diawasi oleh BI, dan mana yang akan diatur dan diawasi oleh Bank Indonesia. Pemerintah juga memahami bahwa proses peralihan pelaksanaan fungsi, tugas dan wewenang dari Bapepam-LK dan Bank Indonesia ke BI harus dilakukan dengan cermat dan hati-hati. Dengan demikian diharapkan akan dapat mengurangi gejolak yang mungkin timbul dalam lingkungan internal institusi lama maupun di lingkungan industri masing-masing secara keseluruhan.

\section{KESIMPULAN DAN SARAN}

Berdasarkan dari hasil penelitian dan pembahasan maka dapat ditarik kesimpulan sebagai berikut : Peran dari BI dalam menjalankan tugas pengaturan dan pengawasan terhadap Lembaga Keuangan di Indonesia menurut UU No. 21 Tahun 2011 merupakan tugas pengaturan dan pengawasan atas lembaga jasa keuangan berbasis ekonomi islam yang sebelumnya telah dilakukan oleh Bank Indonesia dan Bapepam-LK. Dalam kaitan mengatur dan mengawasi perbankan, maka Bank Indonesia berkedudukan sesuai dengan UU No. 21 Tahun 2011 Pasal 40 ayat 1 dan 2. BI sendiri memiliki independensi yang dapat diharapkan mengatur dan mengawasi LK tanpa intervensi dan mampu lebih tegas guna stabilitas jalannya lembaga keuangan, sesuai dengan UU No. 21 Tahun 2011 pasal 2.

Implementasi dari fungsi pengaturan dan pengawasan yang dilaksanakan BI sesuai dengan 
UU No. 21 Tahun 2011 bersifat independen. Pada Undang-Undang No 21 Tahun 2011 tentang BI pasal 66 ayat 2 sendiri disebutkan bahwa Bank Indonesia, menteri Keuangan, dan Bapepam-LK menyampaikan laporan atas pelaksaan fungsi, tugas dan wewenang sebagaimana dimaksud pada ayat (1) kepada BI. BI sendiri memiliki implementasi dalam mengatur dan mengawasi sektor perbankan yang merupakan pengalihan dari tugas Bank Indonesia, sektor pasar modal, perasuransian, dana pensiun dan lembaga pembiayaan syariah yang merupakan pengalihan dari Bapepam-LK. Dengan independensi yang dimiliki, maka BI tidak hanya mengawasi dan mengatur demi stabilitas perekonomian, namun juga memberikan perlindungan terhadap konsumen dengan memberikan pelayanan sesuai BAB VI UU No. 21 Tahun 2011 tentang BI.

UU berkaitan dengan rangkaian UU lain yaitu seperti UU Bank Indonesia, UU Perbankan, UU Lembaga Penjamin Simpanan merupakan suatu Undang-Undang yang engalihkan tugas dan kewenangan dalam mengatur dan mengawasi lembaga keuangan yang ada di Indonesia. UU No. 21 Tahun 2011 tentang BI ini membuat BI memiliki status independensi dan mengatur pengalihan tugas yang selama ini dilaksanakan BI dan Bapepam-LK yang mendominasi dalam mengatur dan mengawasi lembaga keuangan. Namun, UU sendiri memiliki suatu kelemahan di mana belum mengatur mengenai perbankan syariah, keterbatasan kewenangan dalam status independensinya dan bagaimana UU mampu melindungi konsumen sendiri.

\section{DAFTAR RUJUKAN}

Andriansyah, Y. (2009). Kinerja Keuangan Perbankan Syariah di Indonesia dan Kontribusinya bagi Pembangunan Nasional. La Riba Jurnal Ekonomi Islam Vol III, No.2 , 181-196.

Ali, F. (2003). Politik Bank Sentral Posisi Gubernur Bank Indonesia dalam Mempertahankan Independensi. Jakarta: LSPEU.

Daniar. (2014). Transmisi Kebijakan Moneter Syariah: Sebuah Analisa. FALAH Jurnal ekonomi Syariah, 90-102.

Dewianty, S. (2012). Sistem Lembaga Keuangan Syariah. Economic: Jurnal Ekonomi dan Hukum Islam, Vol 2, No.1, 41-70.

Irmayanto, J. (2012). Bank dan Lembaga Keuangan. Jakarta: Universitas Trisakti.

Kep Menkeu No.1169/LMK.01/1991 tentang Kegiatan Sewa Guna Usaha.

Kitab Undang-Undang Hukum Dagang Pasal 246

Kusumaningtuti. (2009). Peranan Hukum dalam Penyelesaian Krisis Perbankan di Indonesia. Jakarta: Raja Grafindo Persada.

Undang-Undang No. 2 Tahun 1992

Undang-Undang No.8 Tahun 1995

Undang-Undang No.13 Tahun 1968

Undang-Undang No.23 Tahun 1999 tentang Bank Indonesia

Nasihin, M. (2012). Segala Hal tentang Hukum Lembaga Pembiayaan. Yogyakarta.

Pandia, F. (2014). Lembaga Keuangan. Jakarta: Rhineka Cipta.

Pradityo, R. (2011). Belum Dibentuk, Idependensi BI Diragukan. Yogyakarta: Universitas Gajah Mada.

Setyawan, A. B. (2012). Pengertian BI untuk Mata Kuliah Bank dan Lembaga Keuangan. Jakarta: Gunadarma.

Sihombing, J. (2011). Butir-Butir Hukum Perbankan. Jakarta: Redcarpet Studio. (2012). Otoritas Jasa Keuangan, Konsep Regulasi dan Implementasi. Jakarta: Universitas Pelita Harapan. 
Yudi Akhmad Sadeli, Antisipasi Atas Kerentanan Pada Lembaga Pembiayaan Syariah Melalui Penataan Kembali Peran BI Sebagai Pengawas Jasa Keuangan Berbasis Ekonomi Islam Sesuai UU no. 21 tahun 2011 |45

Sitompul, Z. (2005). Problematika Perbankan. Bandung: Books Terrace\& Library.

Syariffudin. (2012). Bank Sentral. Jakarta: Universitas Gunadarma.

Syukron, A. (2013). Dinamika Perkembangan Perbankan Syariah di Indonesia. Economic: Jurnal Ekonomi dan Hukum Islam, Vol. 3, No.2 , 28-53.

Zaini, Z. D. (2012). Independensi Bank Indonesia dan Penyelesaian Bank Bermasalah. Bandung: IKAPI CV Keni Media. 